\title{
TOXOPLASMA GONDII GENOTYPES CIRCULATING IN DOMESTIC PIGS IN SERBIA
}

\author{
Ljiljana KURUCA $^{1 *}$, Aleksandra UZELAC ${ }^{2}$, Ivana KLUN ${ }^{2}$, Vesna LALOŠEVIĆ ${ }^{1}$ \\ and Olgica DJURKOVIĆ-DJAKOVIĆ
}

\begin{abstract}
${ }^{1}$ Department of Veterinary Medicine, Faculty of Agriculture, University of Novi Sad, Trg Dositeja Obradovića 8, 21000 Novi Sad, Serbia; ${ }^{2}$ National Reference Laboratory for Toxoplasmosis (NRLToxo), Centre of Excellence for Food- and Vector-borne Zoonoses, Institute for Medical Research, University of Belgrade, Belgrade, Serbia
\end{abstract}

(Received 17 January 2019; accepted 2 May 2019)

Consumption of undercooked or raw pork is considered a significant risk factor for human infection with Toxoplasma gondii. In this study, we investigated the genetic structure of $18 \mathrm{~T}$. gondii strains obtained from slaughter pigs from Northern Serbia (mainly Vojvodina). The examined samples originated from eight pigs from large commercial farms, six backyard pigs and four free-range Mangalica pigs, all found to be positive for either viable T. gondii or T. gondii DNA. Genotyping was attempted from both pig tissues and mouse brains from the bioassays using a multiplex multilocus nested polymerase chain reaction-restriction fragment length polymorphism (Mn-PCR-RFLP) method with seven markers (GRA6, alt. SAG2, PK-1, BTUB, C22-8, CS3 and Apico). Identification was achieved for nine $T$. gondii isolates. Seven isolates were classified as type II and two as type III. These results are consistent with previous studies on animal isolates from Serbia as well as with previous reports that type III is more frequently found in samples from Southern Europe than in those from other parts of the continent. PCR-RFLP

Key words: Toxoplasma gondii, domestic pigs, Serbia, genotypes, Mn-

Toxoplasma gondii is a cosmopolitan zoonotic protozoan, clinically significant for its detrimental effect on the developing fetus, as well as an opportunistic pathogen that causes a severe disease in immunocompromised individuals.

The consumption of raw or undercooked meat of infected animals has long been known as one of the main routes of human infection, and the consumption of such pork is considered highly hazardous (EFSA, 2011).

Despite sexual reproduction (genetic exchange) of $T$. gondii in its definite hosts (Felidae), isolates obtained from humans and animals throughout Europe and North America show a remarkably clonal structure, characterised by three

*Corresponding author; E-mail: pavicic.ljiljana@gmail.com; Phone: 00381 (21) 485-3350 
genetic lineages referred to as types I, II and III (Howe and Sibley, 1995). Type II has been shown to be dominant in human samples, while both types II and III are commonly found in animals (Sibley et al., 2009). In North America, a fourth clonal lineage (also referred to as haplogroup 12 or type 12) has been described, primarily in wildlife (Khan et al., 2011). On the other hand, in Africa, Asia and South America, a much greater genetic diversity is present, with frequent atypical and recombinant strains of $T$. gondii, probably due to a variety of wild felid species, which provide a fertile ground for genetic recombination (Dardé, 2008).

In Serbia, most isolates obtained from human samples have been identified as type II, but one atypical strain has been detected (Djurković-Djaković et al., 2006; Štajner et al., 2013). In animals, genotyping of $T$. gondii strains isolated from pigeons, sheep and horses revealed both type II (pigeons and sheep) and type III (pigeons and horses) (Marković et al., 2014; Klun et al., 2017). In this paper, we present the first data on the $T$. gondii genotypes in pigs from Serbia.

\section{Materials and methods}

Samples. Samples from 18 slaughter pigs in which either viable T. gondii or $T$. gondii DNA was detected by mouse bioassay and PCR, respectively (Kuruca et al., 2016, 2017), were used for strain genotyping. All pigs originated from the territory of Northern Serbia and all but one were from Vojvodina province. Eight of these pigs were raised on large commercial farms, six were backyard pigs and four were free-range pigs of the Mangalica breed (autochthonous to the area). Genotyping was attempted from pig diaphragm digests (or heart, in the case of the Mangalica) as well as from brains of the mice from the bioassay. Since only positive tissues (for either $T$. gondii cysts or DNA) were analysed, for some pigs only one type of sample (either pig tissue or mouse brain) was subjected to genotyping.

Molecular characterisation of $\mathrm{T}$. gondii isolates. Genotyping was performed by the multiplex multilocus nested polymerase chain reaction-restriction fragment length polymorphism (Mn-PCR-RFLP) method (Su et al., 2010) using seven markers. Markers and sequences of the corresponding primers are summarised in Table 1.

Reaction mixtures were prepared according to Su et al. (2006), with few modifications such as use of the commercial 2X PCR Master Mix (Thermo Fischer Scientific, Waltham, MA, USA). Briefly, multiplex PCR reaction was performed in a final volume of $25 \mu 1$ mixture containing $12.5 \mu 1$ of 2X PCR Master Mix, $0.15 \mu \mathrm{M}$ mixture of external forward (F) and reverse (R) primers for each marker, nuclease-free water and 1.5-3 $\mu 1$ of sample DNA. The primer mixture consisted of equal volumes of 14 external primers (seven $\mathrm{F}$ and seven $\mathrm{R}$ ) previously diluted to $0.15 \mu \mathrm{M}$. For the nested PCR reaction, a $25-\mu 1$ mixture was 
prepared separately for each marker and consisted of $12.5 \mu 1$ of 2X PCR Master Mix, $0.30 \mu \mathrm{M}$ of each internal primer, nuclease free water and 2-4 $\mu 1$ of amplification product of the first Mn-PCR reaction. Details of the Mn-PCR-RFLP protocol, adapted to our choice of markers, are presented in Table 2.

After amplification, the PCR products were digested with appropriate restriction enzymes. The digestion mixture consisted of 1-2 $U$ of restriction enzyme, 1X FD buffer (Fast Digest, Thermo Fischer Scientific, Waltham, MA, USA), nuclease-free water and $5 \mu \mathrm{l}$ of Mn-PCR reaction product, in a $25-\mu 1$ reaction volume.

Mn-PCR-RFLP results were visualised by electrophoresis in $2.5 \%$ agarose gel stained with ethidium bromide and read against a 50-bp DNA ladder (Fermentas, Thermo Fischer Scientific, Waltham, MA, USA). RH (type I), Me49 (type II) and NED (type III) strains were used as positive controls and nucleasefree water as negative control.

\section{Results}

After performing Mn-PCR-RFLP on T. gondii strains from 18 pigs (a total of 29 samples, of which 14 were pig tissue digests and 15 mouse brains), identification was achieved for nine isolates. Seven isolates were classified as type II and two as type III (Table 3).

Due to the variations in the efficacy of Mn-PCR-RFLP observed between pig diaphragms and mouse brains from the corresponding bioassay, results are presented for the tissue type that amplified the best. When efficacy was equivalent between the tissues, results obtained from pig tissues were chosen over the results from mouse brain.

\section{Discussion}

Genotyping of $T$. gondii performed in this study revealed the presence of both type II and type III strains in pigs from Northern Serbia. In some of the identified isolates, amplification of one or more markers failed, likely due to the insufficient amount of DNA in the sample (Vujanić, 2012). Lack of DNA was also the probable reason why direct genotyping from pig tissues was successful in only two cases (Table 3, pigs NF48 and BM17). The abundance of T. gondii in tissues of naturally infected pigs may be less than 1 cyst per $50 \mathrm{~g}$ (Dubey et al., 1996), and mouse bioassay may be necessary to increase the parasite load to a detectable level. In this study, the 'boosting' effect of the bioassay was particularly evident in at least one instance (sample 6BM/14, Table 3), where genotyping from the pig tissue failed completely, whereas from the mouse brains, $T$. gondii DNA was extracted in amounts sufficient for the amplification of all seven markers. 


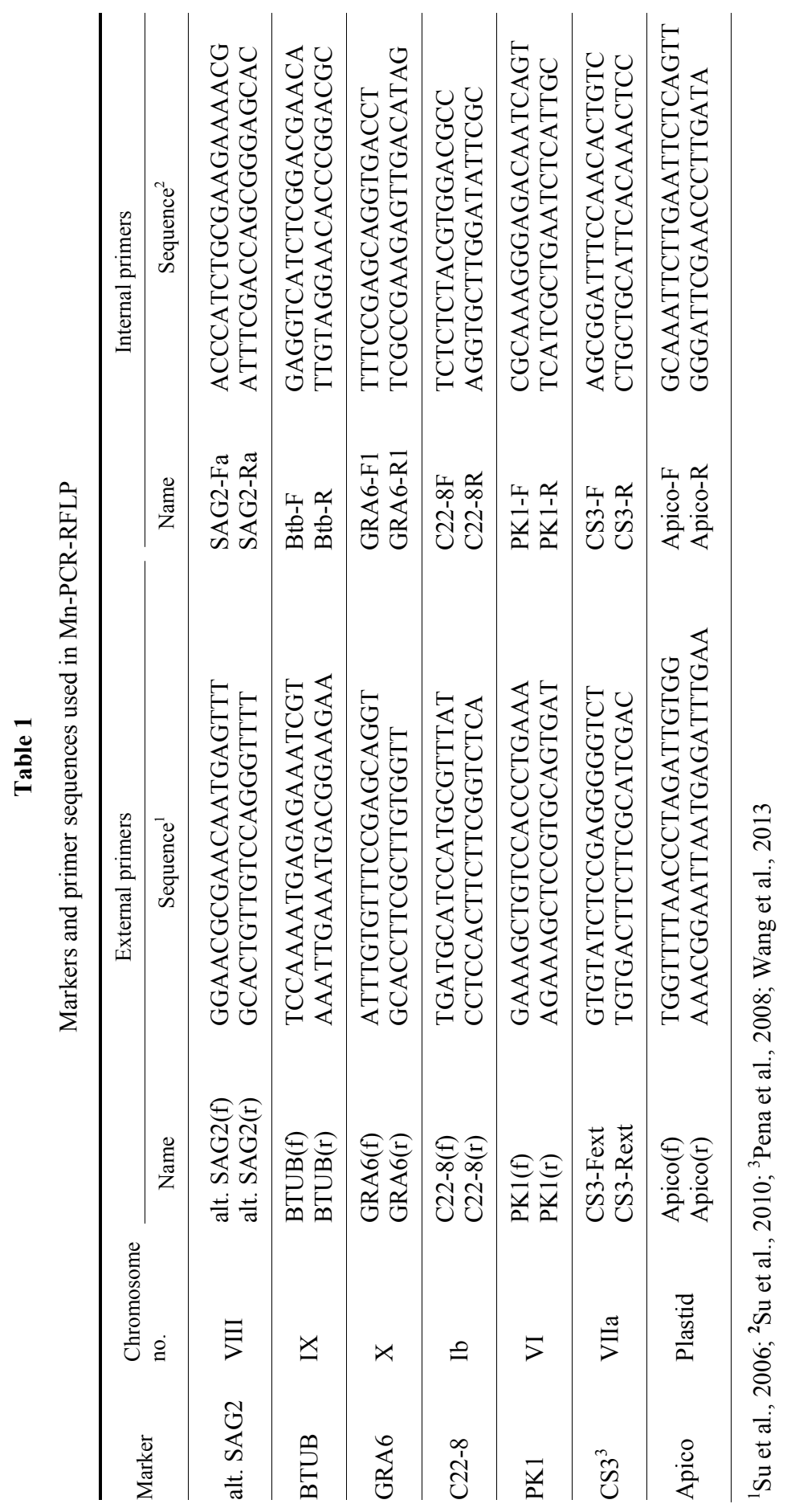




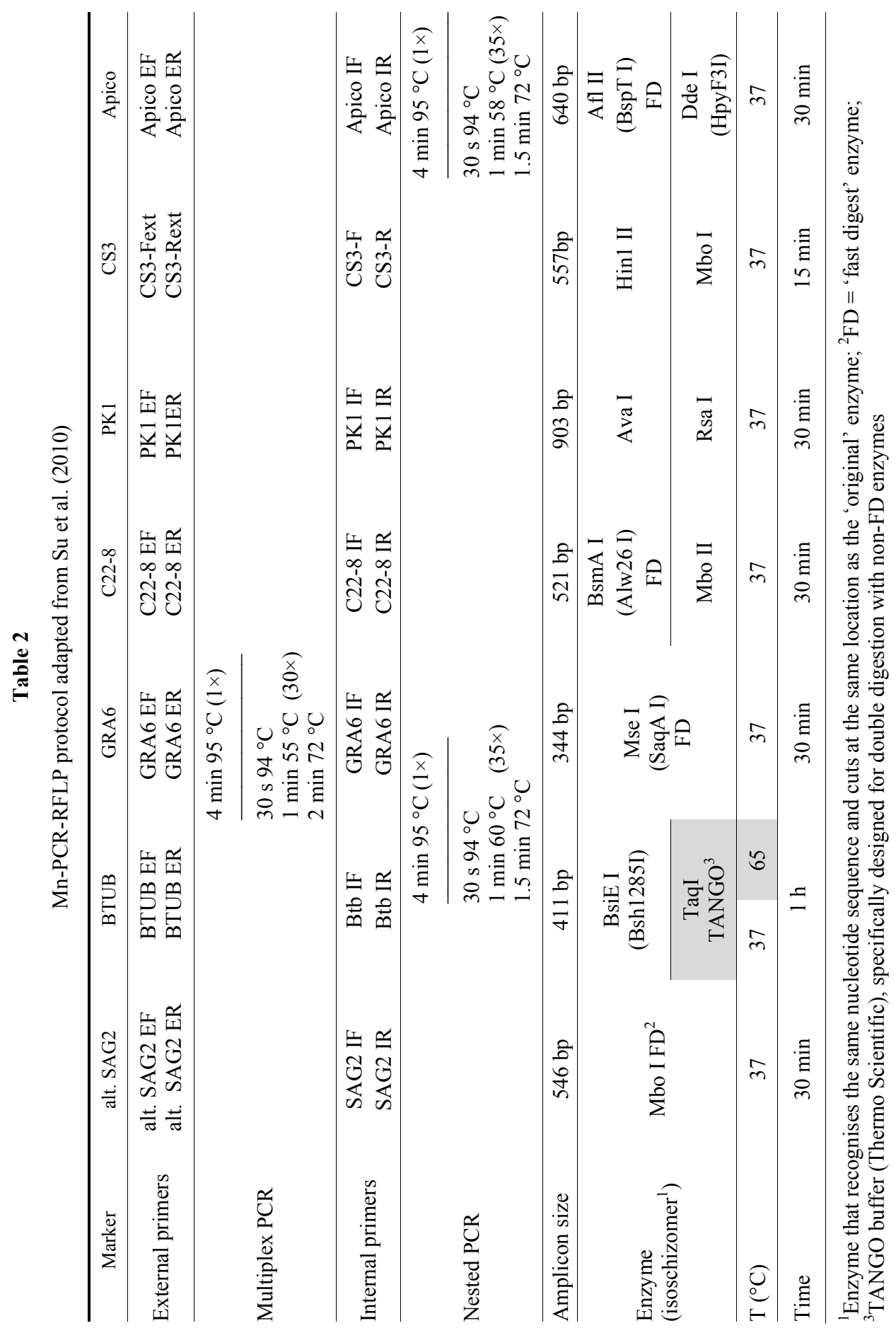


Table 3

Toxoplasma gondii isolates successfully identified by MnPCR-RFLP analysis

\begin{tabular}{|c|c|c|c|c|c|c|c|c|c|c|c|}
\hline \multirow[b]{2}{*}{ No. } & \multirow{2}{*}{$\begin{array}{l}\text { Sample } \\
\text { code }\end{array}$} & \multicolumn{7}{|c|}{ Markers } & \multirow{2}{*}{$\begin{array}{c}T . \\
\text { gondii } \\
\text { Type }\end{array}$} & \multirow{2}{*}{$\begin{array}{c}\text { Pig } \\
\text { origin }\end{array}$} & \multirow{2}{*}{ Tissue $^{\mathrm{a}}$} \\
\hline & & GRA6 & $\begin{array}{c}\text { alt. } \\
\text { SAG2 }\end{array}$ & PK-1 & BTUB & $\mathrm{C} 22-8$ & $\mathrm{CS} 3$ & Apico & & & \\
\hline 1 & NF56/112 & II & II & NA & NA & NA & NA & II & II & $\mathrm{F}$ & brain \\
\hline 2 & $\mathrm{NO} 4 / 145$ & III & III & III & III & III & NA & III & III & B & brain \\
\hline 3 & NF47/105 & II & II & II & II & II & II & II & II & $\mathrm{F}$ & brain \\
\hline 4 & NF48/59 & III & III & NA & III & II & NA & III & III & $\mathrm{F}$ & diaphragm \\
\hline 5 & NF51/66 & II & II & II & II & II & NA & II & II & $\mathrm{F}$ & brain \\
\hline 6 & NF52/108 & II & II & II & II & II & NA & II & II & $\mathrm{F}$ & brain \\
\hline 7 & BM17/113 & NA & II & NA & II & II & NA & II & II & M & diaphragm \\
\hline 8 & NF57/62 & II & II & II & II & II & NA & II & II & $\mathrm{F}$ & brain \\
\hline 9 & $6 \mathrm{BM} / 14$ & II & II & $\mathrm{I} / \mathrm{II}$ & II & II & II & II & II & M & brain \\
\hline
\end{tabular}

$\mathrm{F}=$ farm, $\mathrm{B}=$ backyard/household, $\mathrm{M}=$ Mangalica; NA = not amplified; ${ }^{\mathrm{a}}$ Brain tissues originated from mice, whereas diaphragms originated from pigs

The predominance of type II over type III in pigs from Serbia is in accordance with the results of other studies from Europe, including most recent data from the Czech Republic (Slany et al., 2016), France (Djokic et al., 2016) and Italy (Bacci et al., 2015; Vergara et al., 2018). The results of this study are also consistent with those previously obtained for other animals from Serbia. Using the conventional PCR-RFLP method and a set of six genetic markers (SAG1, 5'SAG2, 3'SAG2, GRA6, 5'GRA7 and 3'GRA7), two pigeon isolates, as well as one sheep isolate, were classified as type II, whereas one pigeon isolate was identified as type III (Marković et al., 2014). Type III has recently also been detected in tissues of two slaughter horses, using microsatellite analysis with 15 markers (Klun et al., 2017). The detection of type III isolates in two pigs in this study supports earlier findings of a greater representation of type III in the countries of Southern Europe (De Sousa et al., 2006; Dubey et al., 2006; Vergara et al., 2018). Due to the region's (relative) geographical vicinity to Africa, it has been suggested that this may be a consequence of the spread (e.g. through bird migrations, transportation and trade of animals and goods etc.) of type III from Africa and/or other countries in which this type is frequent (Mercier et al., 2010; Shwab et al., 2014; Klun et al., 2017).

It is interesting that only type II strains were isolated from the free-range Mangalica pigs, although such a production provides greater opportunity of coming in contact with $T$. gondii, especially since they all originated from a special nature reserve, characterised by high biodiversity of flora and fauna. On the other hand, this finding may be due to the limited number of Mangalica pigs examined in this study and further research, involving more animals, is needed to better understand the $T$. gondii population structure in these pigs. 
Another interesting observation is that one pig (NF48) from which type III was isolated originated from the same farm as the five pigs in which type II isolates were identified, which suggests the circulation of two different types of $T$. gondii in the farm surroundings. Detection of different $T$. gondii lineages in pigs from the same farm has recently been reported by Vergara et al. (2018).

In conclusion, this study presents the first data on the molecular characterisation of T. gondii strains circulating in domestic pigs in Serbia. Detection of both type II and type III strains corroborates the findings of previous studies on animal isolates from this country. The presented results also add to the existing body of data that shows the predominance of type II over type III in animals from Europe, but also the more frequent detection of type III in Southern Europe, compared to other parts of the continent.

\section{Acknowledgement}

This study was supported by the Ministry of Education, Science and Technological Development of the Republic of Serbia (project grants No. TR 31034 and III 41019).

\section{References}

Bacci, C., Vismarra, A., Mangia, C., Bonardi, S., Bruini, I., Genchi, M., Kramer, L. and Brindani, F. (2015): Detection of Toxoplasma gondii in free-range, organic pigs in Italy using serological and molecular methods. Int. J. Food Microbiol. 202, 54-56.

Dardé, M.-L. (2008): Toxoplasma gondii, 'new' genotypes and virulence. Parasite. 15, 366-371.

De Sousa, S., Ajzenberg, D., Canada, N., Freire, L., Da Costa, J. M. C., Darde, M. L., Thulliez, P. and Dubey, J. P. (2006): Biologic and molecular characterization of Toxoplasma gondii isolates from pigs from Portugal. Vet. Parasitol. 135, 133-136.

Djokic, V., Blaga, R., Aubert, D., Durand, B., Perret, C., Geers, R., Ducry, T., Vallee, I., DjurkovićDjaković, O., Mzabi, A., Villena, I. and Boireau, P. (2016): Toxoplasma gondii infection in pork produced in France. Parasitol. 143, 557-567.

Djurković-Djaković, O., Klun, I., Khan, A., Nikolić, A., Knežević-Ušaj, S., Bobić, B. and Sibley, L. D. (2006): A human origin type II strain of Toxoplasma gondii causing severe encephalitis in mice. Microb. Infect. 8, 2206-2212.

Dubey, J. P., Lunney, J. K., Shen, S. K., Kwok, O. C., Ashford, D. and Thulliez, P. (1996): Infectivity of low numbers of Toxoplasma gondii oocysts to pigs. J. Parasitol. 82, 438-443.

Dubey, J. P., Vianna, M. C., Sousa, S., Canada, N., Meireles, S., Correia da Costa, J. M., Marcet, P. L., Lehmann, T., Dardé, M. L. and Thulliez, P. (2006): Characterization of Toxoplasma gondii isolates in free-range chickens from Portugal. J. Parasitol. 92, 184-186.

EFSA (2011): Scientific Opinion on the public health hazards to be covered by inspection of meat (swine). EFSA J. 9, 1-198.

Howe, D. K. and Sibley, L. D. (1995): Toxoplasma gondii comprises three clonal lineages : correlation of parasite genotype with human disease. J. Infect. Dis. 172, 1561-1566.

Khan, A., Dubey, J. P., Su, C., Ajioka, J. W., Rosenthal, B. M. and Sibley, L. D. (2011): Genetic analyses of atypical Toxoplasma gondii strains reveal a fourth clonal lineage in North America. Int. J. Parasitol. 41, 645-655. 
Klun, I., Uzelac, A., Villena, I., Mercier, A., Bobić, B., Nikolić, A., Rajnpreht, I., Opsteegh, M., Aubert, D., Blaga, R., Van der Giessen, J. and Djurković-Djaković, O. (2017): The first isolation and molecular characterization of Toxoplasma gondii from horses in Serbia. Parasit. Vectors 10, 167.

Kuruca, L., Klun, I., Uzelac, A., Nikolić, A., Bobić, B., Simin, S., Djurković-Djaković, O. and Lalošević, V. (2016): Detection of viable Toxoplasma gondii in free-range pigs from the Special Nature Reserve of Zasavica. Contemp. Agric. 65, 1-6.

Kuruca, L., Klun, I., Uzelac, A., Nikolić, A., Bobić, B., Simin, S., Lalošević, D., Lalošević, V. and Djurković-Djaković, O. (2017): Detection of Toxoplasma gondii in naturally infected domestic pigs in Northern Serbia. Parasitol. Res. 116, 3117-3123.

Marković, M., Ivović, V., Štajner, T., Djokić, V., Klun, I., Bobić, B., Nikolić, A. and DjurkovićDjaković, O. (2014): Evidence for genetic diversity of Toxoplasma gondii in selected intermediate hosts in Serbia. Comp. Immunol. Microbiol. Infect. Dis. 37, 173-179.

Mercier, A., Devillard, S., Ngoubangoye, B., Bonnabau, H., Bañuls, A. L., Durand, P., Salle, B., Ajzenberg, D. and Dardé, M. L. (2010): Additional haplogroups of Toxoplasma gondii out of Africa: Population structure and mouse-virulence of strains from Gabon. PLoS Negl. Trop. Dis. 4, e876.

Pena, H. F. J., Gennari, S. M., Dubey, J. P. and Su, C. (2008): Population structure and mousevirulence of Toxoplasma gondii in Brazil. Int. J. Parasitol. 38, 561-569.

Shwab, E. K., Zhu, Xi.-Q., Majumdar, D., Pena, H. F. J., Gennari, S. M., Dubey, J. P. and Su, C. (2014): Geographical patterns of Toxoplasma gondii genetic diversity revealed by multilocus PCR-RFLP genotyping. Parasitol. 141, 453-461.

Sibley, L. D., Khan, A., Ajioka, J. W. and Rosenthal, B. M. (2009): Genetic diversity of Toxoplasma gondii in animals and humans. Philos. Trans. R. Soc. Lond. B Biol. Sci. 364, 2749-2761.

Slany, M., Reslova, N., Babak, V. and Lorencova, A. (2016): Molecular characterization of Toxoplasma gondii in pork meat from different production systems in the Czech Republic. Int. J. Food Microbiol. 238, 252-255.

Štajner, T., Vasiljević, Z., Vujić, D., Marković, M., Ristić, G., Mićić, D., Pašić, S., Ivović, V., Ajzenberg, D. and Djurković-Djaković, O. (2013): Atypical strain of Toxoplasma gondii causing fatal reactivation after hematopoietic stem cell transplantation in a patient with an underlying immunological deficiency. J. Clin. Microbiol. 51, 2686-2690.

Su, C., Shwab, E. K., Zhou, P., Zhu, X. Q. and Dubey, J. P. (2010): Moving towards an integrated approach to molecular detection and identification of Toxoplasma gondii. Parasitol. 137, 1-11.

Su, C., Zhang, X. and Dubey, J. P. (2006): Genotyping of Toxoplasma gondii by multilocus PCRRFLP markers: A high resolution and simple method for identification of parasites. Int. J. Parasitol. 36, 841-848.

Vergara, A., Marangi, M., Caradonna, T., Pennisi, L., Paludi, D., Papini, R., Ianieri, A., Giangaspero, A. and Normanno, G. (2018): Toxoplasma gondii lineages circulating in slaughtered industrial pigs and potential risk for consumers. J. Food Prot. 81, 1373-1378.

Vujanić, M. (2012): Molecular detection and genotyping of Toxooplasma gondii strains isolated in Serbia. PhD Thesis. Faculty of Biology, University of Belgrade, Belgrade, Serbia.

Wang, L., Cheng, H., Huang, K., Xu, Y., Li Y., Du, J., Yu, L., Luo, Q., Wei, W., Jiang, L. and Shen, J. (2013): Toxoplasma gondii prevalence in food animals and rodents in different regions of China: isolation, genotyping and mouse pathogenicity. Parasit. Vectors 6, 273. 